Adegboye OA, Adesiyun OO, Adeboye MAN

\title{
A Short Communication
}

\section{Double Sides of COVID 19 Pandemic: African Countries should Break Grounds or be Permanently Broken}

\author{
Adegboye OA, Adesiyun 00, Adeboye MAN. \\ Department of Paediatrics and Child Health, University of \\ Ilorin/ University of Ilorin Teaching Hospital, Ilorin, Kwara \\ State.
}

\section{ABSTRACT}

\author{
Correspondence \\ Dr Adeboye MAN \\ Email: adeboyeman@gmail.com
}

COVID-19 crept into the world December, 2019, and within a short time, has gone round the whole world and still infecting, affecting and afflicting the all regions of the world. The effect on Africa is grave, not in terms of the morbidity and the mortality, but in terms of its economic impact and the apparent exposure of the weak health system in many parts of Africa. It is hoped that this event will set the governance of the continent right so that the governments will effectively ensure a stronger and more economically vibrant nations emerge after the pandemic.

Keywords: African, Broken, Countries, COVID-19

\section{LITERATURE}

I n December 2019, little did the whole world realized that a novel coronavirus (now called SARS-CoV-2) which was detected in three patients with pneumonia connected to the cluster of acute respiratory illness cases from Wuhan, China was on the verge of taking on the world by storm. ${ }^{1,2}$ It did, and in less than six months, it has affected about four million people and has killed over a quarter of a million and still counting., ${ }^{3,4}$ Following the outbreak in China in late December, and its spread to parts of Asia, Europe, the Middle East and the US, Africa seems to have been spared a major outbreak for months, recording its first confirmed case only on 14 February in Egypt. Though Africa has close ties with China, its risk of importation of COVID-19 based on travel exposure to China is lower compared to Europe (1\% to $11 \%$ respectively $)^{1,2,5}$, By the end of February 2020, several countries were experiencing sustained local transmission of the coronavirus disease. Its rapidity of spread, morbidity and mortality have necessitated some hard decisions with grave economic consequences globally and changed the world apparently permanently. It was declared as a pandemic on $30^{\text {th }}$ of January 2020 by the World Health Organization.

As at $6^{\text {th }}$ of May, 2020, it has affected 212 countries and territories around the world and two international conveyances. Developed countries are the worst hit with the United States of America being the current epicenter of the world accounting for over $30 \%$ of the current global burden with the highest number of mortalities associated with the disease. This is followed by Spain, Italy and the United Kingdom. South Africa, Egypt and Morocco are the top three most affected countries in Africa with 8,232, 7981 and 5,548 positive cases respectively. The respective mortality figures in these countries are 161, 482 and 183. Nigeria is the fifth most affected country in Africa with 3,145 cases and 103 deaths. ${ }^{3,4}$

The rate of infection as well as the case fatality is obviously lower in the Africans compared to the Europeans and the Americans. This notwithstanding, the burden of the 
infection on the economy of the African continent is massive. It has crippled several businesses and the effect of the virus is likely to be aggravated by the means employed by many African countries to control it.. ${ }^{71}$ For instance, with the advent of COVID-19, a pack of surgical face masks that sold for less than two dollars (N500) skyrocketed and sold for 50 dollars (N18,000).

The COVID-19 pandemic is already affecting global food availability, supply chains, and purchasing practices. Panic buying and growing demand for food items are creating a strain on global supply chains while restrictions on trade and movement have had a knock on availability of food stuffs. Price increases will further inhibit equitable access to quality nutritious food. ${ }^{12}$

Aside the effect on economy, COVID-19 has affected several other aspects of human endeavours across the world. From schooling at all levels, to tourism, social gathering, private and government work places, humanity, health care and transportation to list a few. Shortly after the onset of the pandemic, many nations declared different grades of restriction of movement to complete lockdown. In several African countries, declaration of lockdown was accepted by others, and condemned by some, when partial relaxation of the lockdown was declared, it also met similar mixed feelings of acceptance and rejection by significant number of the populace.

This pandemic is obviously not the first and might not be the last, the grave danger with this condition is the ease with which it spreads and the fact that an infected person that is asymptomatic may transmit the disease. ${ }^{1,2,6,13}$ While many African nations are following step by step the management directives by World Health Organization, some self-designed pathway in tackling the novel virus pandemic and variable successful results are reported. Examples of African countries with significant strides following self-created management include Madagascar, Uganda, South Sudan, Central African Republic (CAR). All these countries had cases in excess of 100 as at $12^{\text {th }}$ of May, 2020 with no single mortality. Africa has comparative advantages when it comes to COVID-19., One advantage is its demography. Africa is the youngest continent in the world, with a median age of less than 20 , and it currently seems that younger populations appear to suffer milder symptoms than older people, who have a significantly higher risk of expressing severe symptoms apparently due to old age and presence of co-morbidities and sub-optimal immunity. ${ }^{5,15}$ Madagascar, the world's $47^{\text {th }}$ largest country, second largest Island Country and the $4^{\text {th }}$ largest Island the world over, had a total of 193 cases and 101 have recovered and their economy has been reopened ${ }^{16,17}$ This is an African nation that has produced a medication (Madagascar's COVID-19 Organics) which she claims to have preventive as well as a curative ability for COVID-19. The World Health Organization (WHO) has called for clinical trials of Madagascar's COVID-19 Organics. ${ }^{16}$ This is a great feat.

That the current pandemic will be resolved is not a bone of contention at any level, the focus of divergent opinions is what happens especially to Africa after the pandemic. ${ }^{5,14,18,24}$ Should the continent remain naturally rich, humanly endowed but economically submissive, then she would remain broke permanently. The other option is for the continent to harness her potential and move out of the "potential" to "actualize"zone so that she can remain positively relevant in the scheme of events. This calls for discipline, transparent and purposeful leadership and followership, adequate funding for health and education, massive investment in trade, job creation, citizen vital data bank and security. Every life must be valued.

According to scenario simulations of the International Monetary Fund (IMF), global growth could fall by 0.5 for the year 2020. Several other sources are also predicting a fall in global growth due to the direct effects of the COVID19 outbreak. ${ }^{8,5,9,11}$ The global economy has been projected to enter a recession at least in the first half of the year 2020, when adding the direct and indirect effects of the crisis. U.N. chief Antonio Guterres warned that a global recession, "perhaps of record dimensions", was a near certainty. "This is a moment that demands coordinated, decisive, and innovative policy action from the world's leading economies," he added that "We are in an unprecedented situation and the normal rules no longer apply. ${ }^{25}$ 
Adegboye OA, Adesiyun OO, Adeboye MAN.

As a reactive process, several Governments and policymakers the world over as well as in Africa are slashing interest rates to try to stabilize economies suffering from the impact of quarantined consumers and disrupted supply chains. The stimulus package in Nigeria was the N50bn ( $\$ 128.4 \mathrm{~m})$ Targeted Credit Facility. ${ }^{26,28}$ The COVID-19 pandemic's global cost could range from \$2 trillion to $\$ 4.1$ trillion (2.3\% to $4.8 \%$ of the global gross domestic product) (GDP). Brent oil prices are expected to average \$35 per barrel this year, down from \$64 in 2019 (current price is $\$ 30$ per barrel) l, $^{1026}$

Kevin Sneader and Shubham Singal wrote that the coronavirus is not only a health crisis of immense proportion-it's also an imminent restructuring of the global economic order and recommended that countries should act across five stages, leading from the crisis of today to the next normal that will emerge after the battle against coronavirus has been won. ${ }^{29}$ The five steps were listed as Resolve, Resilience, Return, Reimagination, and Reform. This article is most recommended for most African leaders as only few have actually demonstrated resolve to tackle the crisis headlong talk less of the other four recommended stages according to this model. The summary of the stages is to produce Africans that are truly Africans in thinking and in patriotism. Africans that are disciplined and that want to take charge of their destiny. In other words, just like African trained medical practitioners are able to diagnose and treat their patients, African trained Engineers must be able to identify problems and provide solutions. Biomedical, Computer, electrical engineers and the likes must go beyond white-collar jobs. Tools needed to make life function must be produced in the continent. This is very possible. The continent has all it takes.

Africa should not need to depend on the other parts of the world to develop medication or vaccine for ailments found in Africa. There should be a great collaboration among countries and territories within the continent. This crisis will reveal not just vulnerabilities but opportunities to improve the performance of businesses. There is need to reconsider what is required versus nice to have. The most

West J Med \& Biomed Sci $\mid$ Vol 1 | No 1 | 2020 glaring on this is the acclaimed development of a cure for COVID-19 by Madagascar, an African country. All effort should be made by the continent to support her and recommend any amendment necessary. The fact that zero mortality has been recorded is a pointer to the possibility of the efficacy of the medication. Business leaders in Africa need to anticipate popularly supported changes to policies and regulations as society seeks to avoid, mitigate, and preempt a future health crisis of the kind we are experiencing today.

In most economies, healthcare system changed little since post-World War II. It is necessary to enable the system meet a rapid surge in patient volume, managing seamlessly across in-person and virtual care. Some countries already demonstrated the capacity for this. China and United Arab Emirates are examples here. No African country is able to do this. There were recorded incidents of misappropriation of finances meant to expand medical infrastructures in this novel corona virus pandemic. Public-health approaches, in an interconnected and highly mobile world, must rethink the speed and global coordination with which they need to react. Policies on critical healthcare infrastructure, strategic reserves of key supplies, and contingency production facilities for critical medical equipment will all need to be addressed. The aftermath of the pandemic will also provide an opportunity to learn from a plethora of social innovations and experiments, ranging from working from home to large-scale surveillance. In fact, COVID-19 pandemic was the necessity that gave birth to some inventions in Nigeria when academics and students united to design and produce ventilators in a number of institutions. ${ }^{30,31}$ The pandemic revealed to several tailors that they are able to produce face masks, it revealed that several apparently jobless ones could be gainfully self-employed by producing hand sanitizers and/or liquid soap. It also revealed that many Engineers and technicians can be sensitized to exhibit their innovations such as seen in the production of pedal operated liquid soap, water and hand sanitizer dispensers. With this has come an understanding that several innovations, if adopted permanently, might provide substantial uplift to economic and social welfare. 
In Conclusion, COVID-19 has changed many norms, forced many new orders written, provided several new opportunities. Will African leaders allow the lessons taught to stay and do good to the continent? Only time will tell. Jeroen Kraaijenbrink ${ }^{32}$ identified seven opportunities in the current pandemic. These are: opportunity for more time, opportunity to reflect and reconsider, opportunity for speed and innovation, opportunity for better meetings, opportunity to reconnect and help, opportunity for cleaner environment and opportunity for modesty and acceptance. COVID-19 is a global leveler. Unlike several previous global disasters, it gave no opportunity for the escape of the influential and government officials especially in Africa. It is no respecter of socio-economic class with several dark sides and many bright sides. Its effects will restructure many parts of the world especially those governed by selfless leaders and the nations will come out permanently better than it hit them. It teaches the human race humility that even an invisible organism can reorder the world.

We hereby recommend that post this pandemic, African governments should feel emboldened and should be supported by their citizens to take a more active role in shaping the continent's economic activity. Africa should prevent herself from the dark sides of COVID-19 and take advantage of the bright side. We should be ready to uphold the discipline we have acquired already and ensure that the continent is a better version of herself after the pandemic. Quality education with the capability to produce a world class machinery, medication, materials of global demands and profitability from scratch to completion should be the norm. Africans should produce vaccines for Africans. Government and the led must resolve to make Africa great again so that the abundant resources therein will be made to serve the inhabitants of the land and not any foreign economic power.

\section{REFERENCES}

1. Cui J, Li F, Shi ZL. Origin and evolution of pathogenic coronaviruses. Vol. 17, Nature Reviews Microbiology. Nature Publishing Group; 2019. p. 181-92.
2. Shereen MA, Khan S, Kazmi A, Bashir N, Siddique R. COVID-19 infection: Origin, transmission, and characteristics of human coronaviruses. Vol. 24, Journal of Advanced Research. Elsevier B.V.; 2020. p. 91-8.

3. Worldometer. Coronavirus Cases [Internet]. Worldometer. 2020 [cited 2020 May 7]. p. 1-22. Available from: https://www.worldometers.info/coronavirus/coronaviruscases/\#daily-cases

4. Wang W, Tang J, Wei F. Updated understanding of the outbreak of 2019 novel coronavirus $(2019-\mathrm{nCoV})$ in Wuhan, China. J Med Virol. 2020 Apr 1;92(4):441-7.

5. MIF. Data and analysis from the MO Ibrahim Foundation: COVID-19 in Africa: A call for coordinated governance, improved health structures and better data. 2020.

6. WHO. COVID-19 Situation update for theWHO African Region 15th April 2020. 2020.

7. Global Economic Effects of COVID-19 [Internet]. [cited 2020 May 6]. Available from: https://crsreports.congress.gov

8. AU. Impact of coronavirus (COVID 19) on the African economy. 2020.

9. WTO. Trade set to plunge as COVID-19 Pandemic upends global economy [Internet]. 2020 [cited 2020 May 6]. Available from: http://data.wto.org/.

10. Anyanwu J, Zaccheaus O, Okwara D. COVID-19: A Business Impact Series. 2020.

11. Husain A, Sandstrom S, Greb F, Groader J, Pallanch C. Economic and food security implications of the COVID19 outbreak [Internet]. 2020 [cited 2020 May 6]. Available from: https://www.nepia.com/industry-news/coronavirusoutbreak-impact-on-shipping/

12. Cheilleachair NR. Extremely Poor People Will Go Hungry As Covid-19 Response Measures Hit. 2020.

13. Thompson R. Pandemic potential of 2019-nCoV. Vol. 20, The Lancet Infectious Diseases. Lancet Publishing Group; 2020. p. 280.

14. WHO. COVID-19 Situation Update for the WHO African Region [Internet]. External Situation Report 7. 2020 [cited 2020 May 6]. p. 1-9. Available from: https://apps.who.int/iris/bitstream/handle/10665/331763/S ITREP_COVID-19_WHOAFRO_20200415-eng.pdf

15. Gilbert M, Pullano G, Pinotti F, Valdano E, Poletto C, Boëlle PY, et al. Preparedness and vulnerability of African countries against importations of COVID-19: a modelling study. Lancet. 2020 Mar 14;395(10227):871-7.

16. Callmander MW, Phillipson PB, Schatz GE, Andriambololonera S, Rabarimanarivo M, Rakotonirina 
Adegboye OA, Adesiyun OO, Adeboye MAN.

$\mathrm{N}$, et al. The endemic and non-endemic vascular flora of Madagascar updated. Plant Ecol Evol [Internet]. 2011 [cited 2020 May 10];144(2):121-5. Available from: http://www.mobot.org/MOBOT/Research/curators/pdf/PL ECEVO_2011.pdf

17. Vences M, Wollenberg KC, Vieites DR, Lees DC. Madagascar as a model region of species diversification [Internet]. Vol. 24, Trends in Ecology and Evolution. 2009 [cited 2020 May 10]. p. 456-65. Available from: http://www.mvences.de/p/p1/Vences_A163.pdf

18. WHO calls for clinical trial of Madagascar's virus cure [Internet]. [cited 2020 May 10]. Available from: https://www.aa.com.tr/en/africa/who-calls-for-clinicaltrial-of-madagascars-virus-cure/1832600\#

19. Wang FS, Zhang C. What to do next to control the 2019nCoV epidemic? Vol. 395, The Lancet. Lancet Publishing Group; 2020. p. 391-3.

20. FSIN. 2020 Global Report on food crises by Food Security Information Network.

21. Cash R, Patel V. Has COVID-19 subverted global health? Lancet [Internet]. 2020 May [cited 2020 May 6]; Available from: https://linkinghub.elsevier.com/retrieve/pii/S01406736203 10898

22. Ozili PK. Munich Personal RePEc Archive Covid-19 pandemic and economic crisis: The Nigerian experience and structural causes Covid-19 pandemic and economic crisis: Online at https://mpra.ub.uni-muenchen.de/99424/ MPRA Paper No. 99424, posted 08 Apr 2020 12:37 UTC

23. Martinez-Alvarez M, Jarde A, Usuf E, Brotherton H, Bittaye M, Samateh AL, et al. COVID-19 pandemic in west Africa. 2020 [cited 2020 May 6]; Available from: https://www.pscp.tv/w/1LyxBN1ZOAyxN

24. Nuwagira E, Muzoora C. Is Sub-Saharan Africa prepared for COVID-19? Trop Med Health [Internet]. 2020 Apr 10 [cited 2020 May 6];48(1):18. Available from: https://tropmedhealth.biomedcentral.com/articles/10.1186/ s41182-020-00206-X

25. COVID-19: SG Remarks on Socio-Economic Impacts Report | Africa Renewal [Internet]. [cited 2020 May 10]. Available from: https://www.un.org/africarenewal/news/coronavirus/covid -19-sg-remarks-report-and-fund-socio-economic-impacts

26. Statista. Chart: How Coronavirus Stimulus Packages Compare | Statista [Internet]. statista. 2020 [cited 2020 May 10]. Available from: https://www.statista.com/chart/21496/stimulus-packagescoronavirus-selected-countries/
27. South Africa's stimulus plan in the face of COVID-19 pandemic - Ventures Africa [Internet]. [cited 2020 May 10]. Available from: http://venturesafrica.com/southafricas-stimulus-plan-in-the-face-of-covid-19-pandemic/

28. Nigeria introduces stimulus package to ease coronavirus hit | The Africa Report.com [Internet]. [cited 2020 May 10]. Available from:

https://www.theafricareport.com/25514/nigeriaintroduces-stimulus-package-to-ease-coronavirus-hit/

29. Sneader K, Singal S. Beyond coronavirus: The path to the next normal | McKinsey [Internet]. McKinsey and Company. 2020 [cited 2020 May 10]. p. 1-2. Available from: https://www.mckinsey.com/industries/healthcaresystems-and-services/our-insights/beyond-coronavirusthe-path-to-the-next-normal

30. Onyedinefu G. COVID-19: Nigerian military begins mass production of ventilators, PPE kits - Businessday NG. Businessday [Internet]. 2020 [cited 2020 May 12]; Available from: https://businessday.ng/news/article/covid19-nigerian-military-begins-mass-production-ofventilators-ppe-kits/

31. Economic confidential. COVID-19: Young Inventors, Local Ventilators to Nigeria's Rescue Economic Confidential. Economic Confidential [Internet]. 2020 [cited 2020 May 12]; Available from: https://economicconfidential.com/2020/04/covid19young-inventors-local-ventilators/

32. Kraaijenbrink J. The Bright Side Of Covid-19: Seven Opportunities Of The Current Pandemic [Internet]. Forbes. 2020 [cited 2020 May 11]. Available from: https://www.forbes.com/sites/jeroenkraaijenbrink/2020/03 /23/the-bright-side-of-corona-seven-opportunities-of-thecurrent pandemic / \#5cd54c9d785c 